Document downloaded from:

http://hdl.handle.net/10251/72431

This paper must be cited as:

Perelló Marín, MR.; Marín García, JA.; Marcos Cuevas, J. (2013). Towards a path dependence approach to study management innovation. Management Decision. 51(5):10371046. doi:10.1108/MD-08-2012-0605

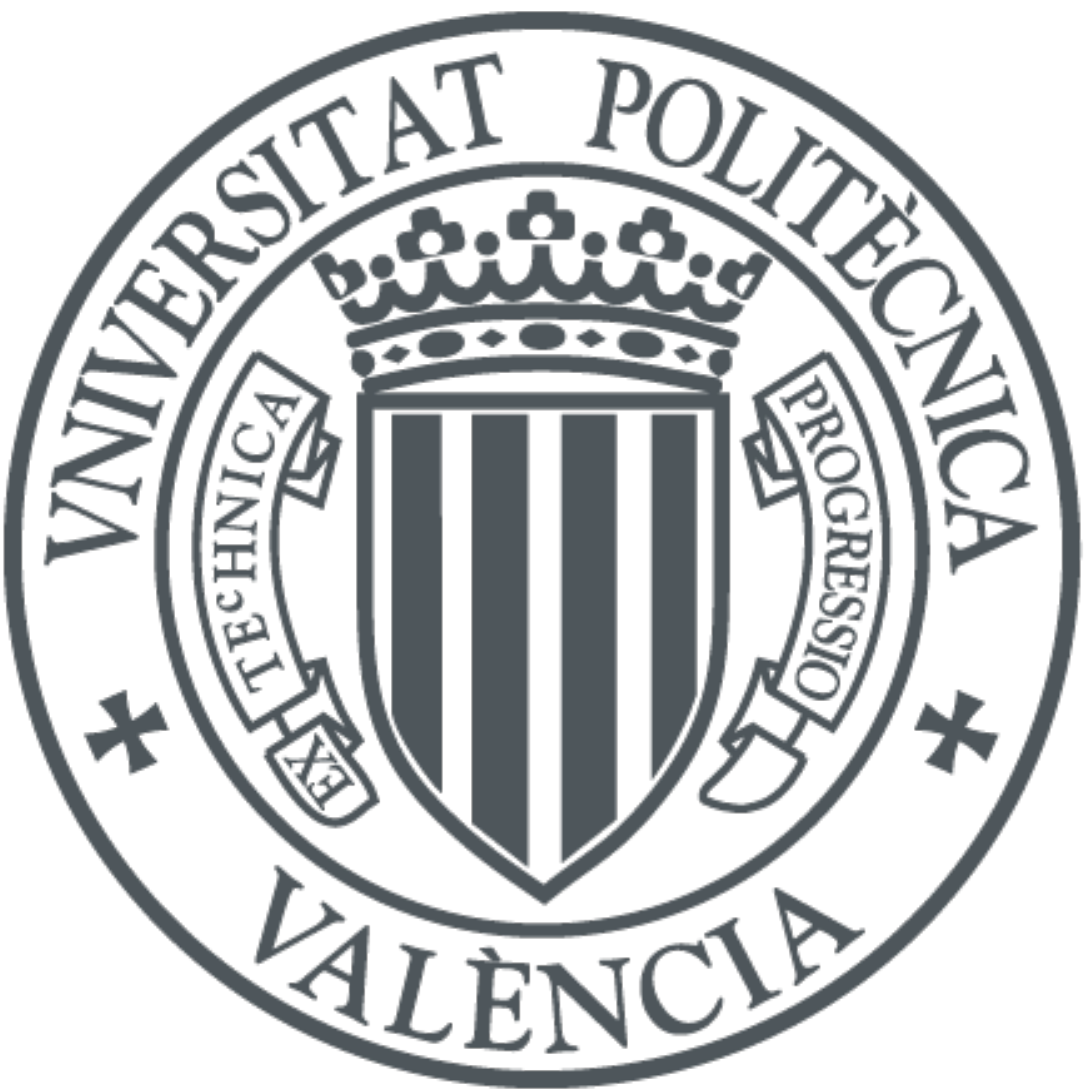

The final publication is available at

http://dx.doi.org/10.1108/MD-08-2012-0605

Copyright Emerald

Additional Information 


\title{
Towards a path dependence approach to study management innovation
}

\author{
M. Rosario Perello-Marin and Juan A. Marin-Garcia \\ Organizacion de empresas, Universidad Politecnica de Valencia, Valencia,Spain, \\ and \\ Javier Marcos-Cuevas \\ Centre for Strategic Marketing and Sales, Cranfield School of Management, \\ Cranfield, UK
}

\begin{abstract}
Purpose - Scholars in social sciences tend to use the term of path dependence without explaining exactly what they mean by it. Path dependence is a useful approach to understand the success or otherwise of the implementation of management innovation. The aim of this paper is to identify under which conditions it makes sense to talk about path dependence, and the relevance of using path dependence to the analysis of management innovation.
\end{abstract}


Design/methodology/approach - The path dependence literature in different contexts and knowledge areas within social science is reviewed using a narrative approach.

Findings - The concept of path dependence can be used to study management innovation, particularly when analyzing the introduction of new management practices. The authors argue that the order in which management practices are introduced has a profound effect on the outcomes for the organization. When the appropriate practices are introduced first, these create enhanced capabilities for the implementation of subsequent practices. If inappropriate practices are rolled out, they may severely impede management innovation and thus evolution and change of the firm.

Research limitations/implications - This work highlights the need to conduct further research to understand the interaction between existing practices and the new ones. This study can be extended with an empirical work to corroborate the results presented here.

Originality/value - By reviewing the different definitions of path dependence that exist in the literature, this paper will stimulate a debate on the necessary and sufficient conditions of path dependence and encourage a greater level of clarity in the management innovation area.

Keywords Path dependence, Management innovation, Management practices, Complexity, Managers, Innovation, Organizational innovation

Paper type Literature review 


\section{Introduction}

In an increasingly competitive environment, in which changes happen so rapidly, organizations endeavor to evolve in order to achieve a sustainable competitive advantage. Firms' emphasis on maximizing flexibility and adaptability to continuous change becomes key to ensure future success changes (Adamides and Pomonis, 2009; Antonelli, 2009; Burnes, 2004b; Farinos et al., 2011; Karlsson and Ahlstrom, 1996; Nielsen and Lassen, 2012a; van Driel and Devos, 2007; Zortea-Johnston et al., 2012). Management innovation (MI) is seen as inextricably linked to change and adaptive abilities (Lei-Yu, 2010; Mol and Birkinshaw, 2009).

We refer to management innovation (MI) as the introduction of management practices that are new to the firm and intended to enhance performance (Mol and Birkinshaw, 2009; Vaccaro et al., 2012). We specially focus on the implementation of innovation in management practices, which affect the day-to-day operational work of managers. The implementation of new practices to obtain a competitive advantage is often a challenge in firms. Whilst some practices succeed in one organization these same practices fail in another, even in organizations operating in comparable environments (Baxter and Hirschhauser, 2004; Bayo-Moriones et al., 2008; Caceres et al., 2011; Corso et al., 2007; Doolen and Hacker, 2005; Garcia-Sabater et al., 2011).

The work described in this paper has been supported by the project "CORSARI MAGIC DPI2010-18243” by the Ministerio de Ciencia e Innovación del Gobierno de España within the Program de "Proyectos de Investigación Fundamental No Orientada". 
The literature focusing on the introduction of new practices and tools at the operational level reveals a number of gaps. The first, is lack of agreement about the reasons (or clusters of reasons) that explain success or failure in the implementation of tools and practices (Akdere, 2009; Albors and Hervás, 2006; Anand and Kodali, 2008; Bhuiyan and Baghel, 2005; Collaine et al., 2002; Doolen and Hacker, 2005; Herron and Braiden, 2006; Hipple, 2005; Marin-Garcia et al., 2011; Mol and Birkinshaw, 2009; Pavnaskar et al., 2003). Second, there is inconclusive evidence about the relationship between the introduction of new management practices and firm performance (Mol and Birkinshaw, 2009). Third, we know little about the importance of the order in which these practices are introduced in the organization. This paper aims to address the third gap.

The introduction of new management practices is a form of MI, this form of MI implies a change in organization, and thus a degree of evolution. Evolution and change in organizations can be studied form different perspectives. In this paper we show how MI can be studied adopting the lens of complexity, and particularly using the "path dependence" approach. In so doing the path dependence approach is explained and how the order chosen to adopt new practices can affect the final outcomes in organizations. We will show that success or failure in implementing new practices and tools depends largely on the interaction between existing practices and the new ones, as well as psychological, organizational, institutional and economic constrains (Baldwin et al., 2005).

The paper is structured as follows. First we link the concept of MI to change and evolution in organizations. Next, we explain how evolution of organizations can be studied from the lens of complexity and we present advantages over other more traditional perspectives. Particularly, we use path dependence as a complexity approach. We present the key different approaches of path dependence used in the literature, and 
finally we conclude with a clear definition of the concept and the conditions under which it occurs.

\section{Approach}

MI can be defined as a difference in the form, quality, or state over time of the management activities in an organization, where the change is a novel or unprecedented departure from the (Birkinshaw et al. 2008). Thus, we can state that there is MI when a firm, seeking to enhance its competitiveness and to increase performance introduces new practices at operational level (Cavagnoli, 2011; Vaccaro et al., 2012). Higher levels of competitiveness and performance will occur provided the introduction of best practices trigger innovation and change.

Organizational change is a critical phenomenon in organizations, but at the same time, difficult to implement successfully (Beckman and Burton, 2008; Burnes, 2004a; Burnes, 2005; Wright et al., 2012). Implementing change has been widely studied and recent developments have drawn on complexity theory (Allen, 2001; Burnes, 2005). Complexity is used as a lens to study the evolution and change aspect of MI, and path dependence is adopted to understand how events or decisions occurred in the past, influence present and future decisions and thus intended change (Antonelli, 2009).

Overall the paper addresses the research question: "Can we study Management Innovation using path dependence approach?" To identify relevant and available studies using path dependence approach and its relevance to MI, we used a variety of search techniques. Electronic searches in citation databases as well as manual searches of relevant journals were performed. Business Source Premier, Web of Knowledge and Science Direct databases where used filtering from 1985 through to June 2012. We began our review in 1985 to coincide with the publishing of David's (1985) study on 
path dependency of QWERTY and subsequently Arthur's (1989) contribution. International journals were searched using key words such as: "path dependence", "evolution", "complexity" and/or "management innovation". We also limited our search to sources written in English.

Manual searches of journals that publish studies on management innovation, and evolution in organizations were also conducted. These journals included: Journal of Business Research, Academy of Management Review, Journal of Management Studies, International Journal of Innovation Management, International Journal of Management Reviews, Research Policy, Journal of Evolutionary Economics and Journal of Cleaner Production. Finally, we also examined the reference lists of the collected articles to identify further relevant papers. In total, the searches resulted in 425 potentially relevant articles that were further narrowed to a final set of 127 included for review.

\section{Complexity}

Complexity theories derive from different scientific disciplines such as biology, physics and mathematics. These theories are being increasingly used to understand the phenomenon of intended change in organizations. In particular, they are deemed useful in deciphering how the adaptability and the capacity to learn and manage change influence performance and survival (Allen, 2001). Complex evolutionary perspectives contribute to our understanding of competitive advantage in a way that traditional research approaches to the study of change in organizations may not, since their underpinning paradigms are deterministic and predictive. In a changing environment, sustainable competitive advantage needs to reflect the dynamic and complex nature of phenomena such as how the organization identifies new niches, exploit them, and then adapt to them, whilst the environment also continues to change (Allen, 2001; Nielsen and Lassen, 2012b). Organizations and their processes and practices are therefore viewed as complex systems. A complex system is such that has within itself a capacity to 
respond to its environment in more than one way (Antonelli, 2009; Burnes, 2005). Such systems have internal possibilities of choice and response over time, that are not always predictable (Allen, 2001).

Within this context, the evolution process of an organization consists of a set of decisions taken by different agents. There is a consensus that decision-making in general, and in management in particular, is plagued by unpredictability, risk and uncertainty (Baldwin et al., 2005; Bergh et al., 2011). Those decisions can be futureoriented or mindful of the past (Guth and Stadler, 2007). The first one corresponds to a pure traditional rational choice behavior, i.e. the traditional economics approach (forward looking deliberation), and the second one, to a new evolutionary theory approach, i.e. evolutionary economics and path dependence approaches.

\section{Path dependence approach}

The notion of path dependence is one of the main forays in the attempt to apply the emerging theory of complexity in economics (Antonelli, 2009). Path dependence is a specific form of complex dynamics: It provides an analytical framework to explain and assess the ever-changing outcomes of the combination of and interaction amongst factors of continuity/discontinuity, growth and development, hysteresis and creativity, routines and "free will", which all characterize economic action in a dynamic perspective that is also able to appreciate the role of historic time (Antonelli, 2009).

The notion of path dependence in social sciences, was first explicitly used to explain prevailing technologies and standards by evolutionary economists in the 1980s (Arthur, 1989; David, 1985). It has been adopted in recent decades as a useful way of analyzing the development of a range of other subjects, including technological development (Bruggeman, 2002; David, 1985; Soriano and Peris-Ortiz, 2011), politics (Bennett and Elman, 2006; Clark and Praneviciute, 2008; Kyriazis and Zouboulakis, 2005; Webster, 
2008), health policy (Monk, 2008), national corporate governance systems (Schmidt and Spindler, 2002), urbanism (Palang et al., 2011; van Assche and Djanibekov, 2012), organizational studies (Lichtenthaler and Muethel, 2012; Sydow et al., 2009), tourism (Bramwell and Cox, 2009), transport (Dooms et al., 2012; Low and Astle, 2009; Mu et al., 2011), industrial clusters (Belussi and Sedita, 2009), management operations (van Driel and Devos, 2009), scientific knowledge (Choi, 2011; Niosi, 2000; Peacock, 2009), export behavior (Casillas et al., 2012), energy (Christiansen, 2002) and innovation systems (Alkemade et al., 2009; Antonelli, 2009; Hakansson and Waluszewski, 2002; MartinezNoya and Garcia-Canal, 2011; Rajneesh, 2002).

Most of the literature about path dependence has been developed from the point of view of technical paths or technical change; however, the study of organizational change presents specific problems due to its complexity and multifaceted nature compared to technological paths (Sydow et al., 2009; van Driel and Dolfsma, 2009).

Although there are increasing discussions of path dependence in social sciences, there is however, substantial disagreement on how best to define and apply the path dependence concept (Pierson, 2000; Vergne and Durand, 2010): whether a deterministic or stochastic approach. Despite the scientific relevance of the approach, path dependence is still contested (Vergne and Durand, 2010). The most commonly conception used by scholars is the deterministic one. It suggests that once a particular course of action has been chosen, it becomes increasingly difficult over time to reverse that course (Pierson, 2000; Schmidt and Spindler, 2002; Webster, 2008). In other words, decisions taken at the present are strongly conditioned by decisions taken in the past. Many contributions refer to path dependence to illuminate organizational rigidities, stickiness, or inflexibility, however most of them are related to similar concepts that are not exactly the same as path dependence (Sydow et al., 2009; Vergne and Durand, 2010) including imprinting (Beckman and Burton, 2008; Johnson, 2007), escalating commitment, abortive capacity, sunk cost (Schmidt and 
Spindler, 2002), structural inertia, reactive sequences or first-mover advantage (Choi, 2008; Chu, 2009).

The stochastic point of view for path dependence assumes that although this approach connects the past and the present, initial conditions do not determine the outcome. A series of contingent (unpredictable or random) events influences on the path taken greater than the initial conditions themselves (Bellaiche, 2010; Marciano and Khalil, 2012). Therefore, novel paths emerge unexpectedly (Allen et al., 2006; Arthur, 1989; Baldwin et al., 2005; David, 1985; David, 2007).

Deterministic approaches have viewed path-dependence as "historicity", whereby initial conditions typically exert strong effects on its development and on the final outcome (Antonelli, 2009). We argue that path dependence cannot be fully explained adopting extreme deterministic approaches, thus "history matters" but do not fully determine future outcomes. Path dependence informs but cannot predict every possible reason why institutions, technological standards, or firm capabilities tend to persist over time (Vergne and Durand, 2010).

While the components that characterize path dependence taken individually can be commonly found in organizations, truly path dependent phenomena are rare. The combination of factors that is required to generate path dependence is less common (Vergne and Durand, 2010). This leads us to argue that path dependence is often defined rather narrowly, and used metaphorically rather than on solid theoretical foundations (Sydow et al., 2009). There are very few references outlining in detail the characteristics or drivers that make organizations path-dependent. Much literature refers to path dependence as a mere label for a particular class of dynamic phenomena, but not as a theory to explain the way in which systems behave and evolve (David, 2007; Vergne and Durand, 2010). Developing a full conceptualization of path dependence, may allow a 
better understanding of organizations' evolution when responding to external stimuli and planned change. Path dependence has potential in enlightening the influence on the final results, of the order in which different practices are implemented (van Driel and Dolfsma, 2009).

Reviewing scholarly work of path dependence reveals two opposite positions: persistence versus novelty. On one hand there is a school of thought that defines path dependence as a mere persistence or rigidity, which can be easily confused by increasing returns, sunk costs or adaptive expectations. We find this approach limited and partial (Sydow et al., 2009; Beckman and Burton, 2008). On the other hand there are some other scholars who defend that novel paths emerge unexpectedly (Allen et al., 2006; Arthur, 1989; Baldwin et al., 2005; David, 1985; David, 2007). Accordingly, such mechanisms would contribute to path dependence only as amplifiers of "small events and chance circumstances". Following this view, the true origin of paths would be unexpected and non-deterministic (van Driel and Dolfsma, 2009; Vergne and Durand, 2010).

We argue that path dependence does not imply inflexibility or non-evolution but quite the opposite. It is a way to evolve taking into account the effect of the past. Path dependence is a specific form of complex system's dynamics most apt to understand the process and the outcomes of the interactions amongst agents embedded in their own context and constrained by their past decisions, yet endowed with creativity and able to generate new knowledge by means of both learning and intentional innovative strategies (Antonelli, 2009). Therefore, path dependence is a dynamic approach that differs from the deterministic one in that irreversibility arises from events along the path. They are not only the initial conditions that play a role in the multiplicity of possible outcomes in organizational evolution (Antonelli, 2009; Vergne and Durand, 2010). Path dependence is the conceptualization of historical dynamics in which one "accident" follows another relentlessly and unpredictably. Yet the past narrows the scope of possible 
outcomes, shaping the corridor into which future dynamics take place (Antonelli, 2009).

\section{Conclusion}

There is no clear consensus on the exact definition of a path dependence process. We propose path dependence to be a stochastic process, that emerges under two conditions (contingency and self-reinforcement) and that causes lock-in in the absence of exogenous shock (Vergne and Durand, 2010). Path dependence can be useful to explain how an organization selects and implements best practices at an operational level, in order to achieve a competitive advantage.

Initial conditions, such as previously implemented practices, successfully or not, observed experiences in competitors, etc., influence the decisions taken in selecting the introduction of new sets of practices. Success or failure in implementing new practices and tools depends largely on the interaction between the existing practices and the new ones. If the appropriate practices are introduced first, these create enhanced capabilities for the implementation of subsequent practices. When inappropriate practices are rolled out, they undermine the organization's ability to introduce seamless management innovation jeopardizing evolution and change of the firm.

Firms compete in an environment where the degree of change is ongoing. To ensure their survival, firms need to adapt the organization at all levels to new circumstances. MI needs to be analyzed adopting dynamic perspectives such as those offered by complexity theories. We invite future research to focus on furthering our understanding of implementation of management practices. Fruitful work may derive from analyzing further when and how the order in which practices are implemented influence the 
achievement of specific results within the organization and also within networks of organizations.

\section{References}

Adamides, E.D. and Pomonis, N. (2009), "The co-evolution of product, production and supply chain decisions, and the emergence of manufacturing strategy", International Journal of Production Economics, Vol. 121 No. 2, pp. 301-312.

Akdere, M. (2009), "The role of knowledge management in quality management practices: achieving performance excellence in organizations", Advances in Developing Human Resources, Vol. 11 No. 3, pp. 349-361.

Albors, J. and Herva's, J.L. (2006), "CI practice in Spain: its role as a strategic tool for the firm. Empirical evidence from the CINet survey analysis", International Journal of Technology Management, Vol. 35 No. 5, pp. 380-396.

Alkemade, F., Frenken, K., Hekkert, M.P. and Schwoon, M. (2009), “A complex systems methodology to transition management", Journal of Evolutionary Economics, Vol. 19 No. 4, pp. 527-543.

Allen, P.M. (2001), “A complex systems approach to learning in adaptive networks", International Journal of Innovation Management, Vol. 5 No. 2, pp. 149-180.

Allen, P.M., Strathern, M. and Baldwin, J.S. (2006), "Evolutionary drive: new understandings of change in socio-economic systems", Emergence: Complexity \& Organization, Vol. 8 No. 2, pp. 2-19. 
Anand, G. and Kodali, R. (2008), "Selection of lean manufacturing systems using the PROMETHEE", Journal of Modelling in Management, Vol. 3 No. 1, pp. 40-70.

Antonelli, C. (2009), "The economics of innovation: from the classical legacies to the economics of complexity", Economics of Innovation \& New Technology, Vol. 18 No. 7 , pp. 611-646.

Arthur, W.B. (1989), "Competing technologies, increasing returns, and lock-in by historical events", Economic Journal, Vol. 99 No. 394, pp. 116-131.

Baldwin, J.S., Allen, P.M., Winder, B. and Ridgway, K. (2005), "Modelling manufacturing evolution: thoughts on sustainable industrial development", Journal of Cleaner Production, Vol. 13 No. 9, pp. 887-902.

Baxter, L.F. and Hirschhauser, C. (2004), "Reification and representation in the implementation of quality improvement programmes", International Journal of Operations \& Production Management, Vol. 24 Nos 1/2, pp. 207-224.

Bayo-Moriones, A., Bello-Pintado, A. and Merino-Diaz-De-Cerio, J. (2008), “The role of organizational context and infrastructure practices in JIT implementation", International Journal of Operations \& Production Management, Vol. 28 Nos 11-12, pp. 1042-1066.

Beckman, C.M. and Burton, M.D. (2008), "Founding the future: path dependence in the evolution of top management teams from founding to IPO", Organization Science, Vol. 19 No. 1, pp. 3-24.

Bellaiche, J. (2010), "On the path-dependence of economic growth", Journal of Mathematical Economics, Vol. 46 No. 2, pp. 163-178. 
Belussi, F. and Sedita, S.R. (2009), "Life cycle vs multiple path dependency in industrial districts", European Planning Studies, Vol. 17 No. 4, pp. 505-528.

Bennett, A. and Elman, C. (2006), "Complex causal relations and case study methods: the example of path dependence", Political Analysis, Vol. 14 No. 3, pp. 250-267.

Bergh, P., Thorgren, S. and Wincent, J. (2011), "Entrepreneurs learning together: the importance of building trust for learning and exploiting business opportunities", International Entrepreneurship and Management Journal, Vol. 7 No. 1, pp. 17-37.

Bhuiyan, N. and Baghel, A. (2005), "An overview of continuous improvement: from the past to the present", Management Decision, Vol. 43 No. 5, pp. 761-771.

Birkinshaw, J., Hamel, G. and Mol, M.J. (2008), "Management innovation", Academy of management Review, Vol. 33 No. 4, pp. 825-845.

Bramwell, B. and Cox, V. (2009), "Stage and path dependence approaches to the evolution of a national park tourism partnership", Journal of Sustainable Tourism, Vol. 17 No. 2, pp. 191-206.

Bruggeman, D. (2002), "NASA: a path dependent organization", Technology in Society, Vol. 24 No. 4, pp. 415-431.

Burnes, B. (2004a), "Emergent change and planned change - competitors or allies?" International Journal of Operations \& Production Management, Vol. 24 No. 9, pp. 886902. 
Burnes, B. (2004b), "Kurt Lewin and complexity theories: back to the future?" Journal of Change Management, Vol. 4 No. 4, pp. 309-325.

Burnes, B. (2005), "Complexity theories and organizational change", International Journal of Management Reviews, Vol. 7 No. 2, pp. 73-90.

Caceres, R., Guzman, J. and Rekowski, M. (2011), "Firms as source of variety in innovation: influence of size and sector", International Entrepreneurship and Management Journal, Vol. 7 No. 3, pp. 357-372.

Casillas, J.C., Moreno, A.M. and Acedo, F.J. (2012), "Path dependence view of export behaviour: a relationship between static patterns and dynamic configurations", International Business Review, Vol. 21 No. 3, pp. 465-479.

Cavagnoli, D. (2011), “A conceptual framework for innovation: an application to human resource management policies in Australia", Innovation-Management Policy \& Practice, Vol. 13 No. 1, pp. 111-125.

Choi, Y.B. (2008), "Path dependence and the Korean alphabet", Journal of Economic Behavior \& Organization, Vol. 65 No. 2, pp. 185-201.

Choi, Y.B. (2011), "Path dependence and the Korean keyboard", Journal of Economic Behavior \& Organization, Vol. 88, April, pp. 37-46.

Christiansen, A.C. (2002), "New renewable energy developments and the climate change issue: a case study of Norwegian politics", Energy Policy, Vol. 30 No. 3, pp. 235-243. 
Chu, W.W. (2009), “Can Taiwan's second movers upgrade via branding?” Research Policy, Vol. 38 No. 6, pp. 1054-1065.

Clark, T.D. and Praneviciute, J. (2008), "Perspectives on communist successor parties: the case of Lithuania”, Communist and Post-Communist Studies, Vol. 41 No. 4, pp. 443464.

Collaine, A., Lutz, P. and Lesage, J.J. (2002), “A method for assessing the impact of product development on the company", International Journal of Production Research, Vol. 40 No. 14, pp. 3311-3336.

Corso, M., Giacobbe, A., Martini, A. and Pellegrini, L. (2007), "Tools and abilities for continuous improvement: what are the drivers of performance", International Journal of Technology Management, Vol. 37 Nos 3-4, pp. 348-365.

David, P.A. (1985), "Clio and the Economics of QWERTY", American Economic Review, Vol. 75 No. 2, pp. 332-337.

David, P.A. (2007), "Path dependence: a foundational concept for historical social science”, Cliometrica, Vol. 1 No. 2, pp. 91-114.

Doolen, T.L. and Hacker, M.E. (2005), “A review of lean assessment in organizations: an exploratory study of lean practices by electronics manufacturers", International Journal of Manufacturing Systems, Vol. 24 No. 1, pp. 55-67.

Dooms, M., Verbeke, A. and Haezendonck, E. (2012), "Stakeholder management and path dependence in large-scale transport infrastructure development: the port of Antwerp case (1960-2010)", Journal of Transport Geography, Vol. 27, February, pp. 14-25. 
Farinos, J., Herrero, B. and Latorre, M. (2011), "Corporate entrepreneurship and acquisitions: creating firm wealth", International Entrepreneurship and Management Journal, Vol. 7 No. 3, pp. 325-339.

Garcia-Sabater, J.J., Marin-Garcia, J.A. and Perello-Marin, M.R. (2011), "Is implementation of continuous improvement possible? An evolutionary model of enablers and inhibitors", Human Factors and Ergonomics in Manufacturing, Vol. 22 No. 2, pp. 99-112.

Guth, W. and Stadler, M. (2007), "Path dependence without denying deliberation. A continuous transition model connecting teleology and evolution", Journal of Evolutionary Economics, Vol. 17 No. 1, pp. 45-52.

Hakansson, H. and Waluszewski, A. (2002), "Path dependence: restricting or facilitating technical development?” Journal of Business Research, Vol. 55 No. 7, pp. 561-570.

Herron, C. and Braiden, P.M. (2006), "A methodology for developing sustainable quantifiable productivity improvement in manufacturing companies", International Journal of Production Economics, Vol. 104 No. 1, pp. 143-153.

Hipple, J. (2005), "The integration of TRIZ with other ideation tools and processes as well as with psychological assessment tools", Creativity \& Innovation Management, Vol. 14 No. 1, pp. 22-33.

Johnson, V. (2007), "What is organizational imprinting? Cultural enterpreneurship in the founding of the Paris Opera", American Journal of Sociology, Vol. 113 No. 1, pp. 97-127. 
Karlsson, C. and Ahlstrom, P. (1996), "The difficult path to lean product development", Journal of Product Innovation Management, Vol. 13 No. 4, pp. 283295.

Kyriazis, N.C. and Zouboulakis, M.S. (2005), "Modeling institutional change in transition economies", Communist and Post-Communist Studies, Vol. 38 No. 1, pp. 109-120.

Lei-Yu, W. (2010), "Which companies should implement management innovation? A commentary essay", Journal of Business Research, Vol. 63 No. 3, pp. 321-323.

Lichtenthaler, U. and Muethel, M. (2012), "The role of deliberate and experiential learning in developing capabilities: insights from technology licensing”, Journal of Engineering and Technology Management, Vol. 29 No. 2, pp. 187-209.

Low, N. and Astle, R. (2009), "Path dependence in urban transport: an institutional analysis of urban passenger transport in Melbourne, Australia, 1956-2006", Transport Policy, Vol. 16 No. 2, pp. 47-58.

Marciano, A. and Khalil, E.L. (2012), "Optimization, path dependence and the law: can judges promote efficiency?", International Review of Law and Economics, Vol. 32 No. 1, pp. 72-82.

Marin-Garcia, J.A., Miralles Insa, C., Garcia-Sabater, J.J. and Perello-Marin, M.R. (2011), "Alternative tools to mass production and human performance indicators in sheltered work centers of Valencian community (Spain)", Journal of Industrial Engineering and Management, Vol. 4 No. 3, pp. 467-480. 
Martinez-Noya, A. and Garcia-Canal, E. (2011), "Technological capabilities and the decision to outsource/outsource offshore services", International Business Review, Vol. 20 No. 3, pp. 264-277.

Mol, M.J. and Birkinshaw, J. (2009), "The sources of management innovation: when firms introduce new management practices", Journal of Business Research, Vol. 62 No. 12, pp. 1269-1280.

Monk, A.H.B. (2008), "The interplay between social welfare and competitiveness: the case of Canadian Medicare", Geoforum, Vol. 39 No. 6, pp. 2009-2018.

Mu, R., Jong, M.D. and Koppenjan, J. (2011), "The rise and fall of Public-Private Partnerships in China: a path-dependent approach", Journal of Transport Geography, Vol. 19 No. 4, pp. 794-806.

Nielsen, S. and Lassen, A. (2012a), "Identity in entrepreneurship effectuation theory: a supplementary framework", International Entrepreneurship and Management Journal, Vol. 8 No. 3, pp. 373-389.

Nielsen, S. and Lassen, A. (2012b), "Images of entrepreneurship: towards a new categorization of entrepreneurship", International Entrepreneurship and Management Journal, Vol. 8 No. 1, pp. 35-53.

Niosi, J. (2000), "Science-based industries: a new Schumpeterian taxonomy", Technology in Society, Vol. 22 No. 4, pp. 429-444.

Palang, H., Spek, T. and Stenseke, M. (2011), "Digging in the past: new conceptual models in landscape history and their relevance in peri-urban landscapes", Landscape and Urban Planning, Vol. 100 No. 4, pp. 344-346. 
Pavnaskar, S.J., Gershenson, J.K. and Jambekar, A.B. (2003), "Classification scheme for lean manufacturing tools", International Journal of Production Research, Vol. 41 No. 13, pp. 3075-3090.

Peacock, M.S. (2009), "Path dependence in the production of scientific knowledge", Social Epistemology, Vol. 23 No. 2, pp. 105-124.

Pierson, P. (2000), "Increasing returns, path dependence, and the study of politics", American Political Science Review, Vol. 94 No. 2, pp. 251-267.

Rajneesh, N. (2002), "Innovation systems and inertia in location: Norwegian firms and the role of systemic lock-in", Research Policy, Vol. 31 No. 5, pp. 795-816.

Schmidt, R.H. and Spindler, G. (2002), "Path dependence, corporate governance and complementarity", International Finance, Vol. 5 No. 3, pp. 311-333.

Soriano, D.R. and Peris-Ortiz, M. (2011), "Subsidizing technology: how to succeed", Journal of Business Research, Vol. 64 No. 11, pp. 1224-1228.

Sydow, J., Chrey, G. and Och, J. (2009), “Organizational path dependence: opening the black box", Academy of Management Review, Vol. 34 No. 4, pp. 689-709.

Vaccaro, I.G., Jansen, J.J.P., Van Den Bosch, F.A.J. and Volberda, H.W. (2012), "Management innovation and leadership: the moderating role of organizational size", Journal of Management Studies, Vol. 49 No. 1, pp. 28-51.

van Assche, K. and Djanibekov, N. (2012), "Spatial planning as policy integration: the need for an evolutionary perspective. Lessons from Uzbekistan", Land Use Policy, Vol. 29 No. 1, pp. 179-186. 
van Driel, H. and Devos, G. (2007), "Path dependence in ports: the persistence of cooperative forms", Business History Review, Vol. 81 No. 4, pp. 681-708.

van Driel, H. and Dolfsma, W. (2009), "Path dependence, initial conditions, and routines in organizations: the Toyota production system re-examined", Journal of Organizational Change Management, Vol. 22 No. 1, pp. 49-72.

Vergne, J.P. and Durand, R. (2010), "The missing link between the theory and empirics of path dependence: conceptual clarification, testability issue, and methodological implications", Journal of Management Studies, Vol. 47 No. 4, pp. 736-759.

Webster, M. (2008), "Incorporating path dependency into decision-analytic methods: an application to global climate-change policy”, Decision Analysis, Vol. 5 No. 2, pp. 60-75.

Wright, C., Sturdy, A. and Wylie, N. (2012), "Management innovation through standardization: Consultants as standardizers of organizational practice WRIGHT2012", Research Policy, Vol. 41 No. 3, pp. 652-662.

Zortea-Johnston, E., Darroch, J. and Matear, S. (2012), "Business orientations and innovation in small and medium sized enterprises", International Entrepreneurship and Management Journal, Vol. 8 No. 2, pp. 145-164.

Corresponding author

M. Rosario Perello-Marin can be contacted at: rperell@upvnet.upv.es 